\title{
PYREX: A Summary of Findings
}

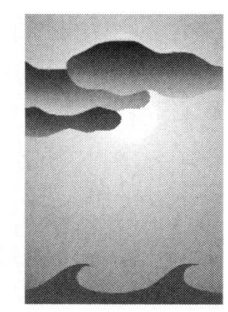

\author{
P. Bougeault, ${ }^{*}$ B. Benech,+ P. Bessemoulin,* B. Carissimo," \\ A. Jansa Clar, ${ }^{@}$ J. Pelon, ${ }^{\&}$ M. Petitdidier,** and E. Richard ${ }^{+}$
}

\begin{abstract}
About six years ago, the planned field experiment Pyrenean Experiment (PYREX) was presented in the Bulletin. After a successful field phase in October and November 1990, and much work to prepare a consistent database, interpret the measurements, and compare model results with observations, it is possible to present today a summary of scientific results. New insight has been obtained in the areas of mountain drag measurement and interpretation, humidity measurement, boundary layer measurement by lidar, the ability of mesoscale models to represent orographic flows, the roughness length of mountains, and parameterization of subgrid-scale gravity waves. The present paper summarizes these results and may be understood as an introduction to this unique dataset on orographic flows. The authors believe that much interesting research can still be achieved with the PYREX data, which are accessible to any interested scientist.
\end{abstract}

\section{Introduction}

Pyrenean Experiment (PYREX, Bougeault et al. 1990) was a field program held in October and November 1990 around the Pyrénées, a mesoscale mountain range that forms the border between France and Spain. The size of the range is about $400 \mathrm{~km} \times 100 \mathrm{~km}$ and the crestline is around $3000 \mathrm{~m}$. In addition to mountain waves and the Foehn, the Pyrénées are believed to be responsible for the existence of three regional winds of high intensity and frequency: the Autan in the vicinity of Toulouse (France), the

*Centre National de Recherches Météorologiques, Toulouse, France.

+Laboratoire d'Aérologie, Toulouse, France.

"Electricité de France, Direction des Etudes et Recherches, Chatou, France.

${ }^{\circledR}$ Instituto Nacional de Meteorología, Palma de Mallorca, Spain.

\&Service d'Aéronomie, Paris, France.

**Centre d'Etude des Environnements Terrestre et Planétaires, Saint-Maur, France.

Corresponding author address: Dr. P. Bougeault, Centre National de Recherches Météorologiques, Groupe de Météorologie a Moyenne Échelle, 42, avenue Gustave Coriolis, 31057 Toulouse Cedex, France.

In final form 18 October 1996.

(C)1997 American Meteorological Society
Tramontana on the Mediterranean, and the Cierzo in the valley of the Ebro River (Spain). These winds represent a forecasting challenge with a serious economic impact. As a clear manifestation of split flow, they are also part of current scientific problems of orographic flows. Finally, they generate intense turbulence, and the induced dissipation of larger-scale kinetic energy must be taken into account when considering the impact of the range on the synoptic flow.

The scientific objectives were therefore centered on the description of the regional atmospheric momentum budget in this area of complex orography.

- Measure the mountain pressure drag, the wave momentum flux, and the possible turbulence inside mountain waves.

- Improve the knowledge of the wind distribution all around the range, including quantitative measurements of turbulent friction at the surface and aloft.

- Determine accurately the deceleration of the synoptic flow by a mix of the above measurements and model simulations.

This cooperative program was supported by several European agencies: Météo-France (the French weather service), the Centre National de la Recherche Scientifique, the Instituto Nacional de Meteorología 
(the Spanish weather service), Electricité de France (EDF), the Deutsche Luft und Raum Forschungsanstalt (DLR), the Centre National d'Etudes Spatiales (CNES), and the Région Midi-Pyrénées. The investigators were affiliated with French, Spanish, and German institutes active in atmospheric research. A list of these institutes and their acronyms may be found in Table 1 .

\section{The field phase and the database}

The field phase is best summarized by the surface networks in Fig. 1, typical flight patterns (Figs. 2 and 3), and the summary of operations during the intensive observation periods (IOPs) in Table 2. The field phase was characterized by a typical succession of orographically influenced events, as the 1990 fall season was, by chance, representative of the regional climate. An early account of the field phase results was published by Bougeault et al. (1993b). The database is described by Bougeault et al. (1993a), and an exhaustive list of PYREX literature has been compiled by Bougeault et al. (1996), along with a more exhaustive presentation of scientific results (in French). The main characteristics of data retained in the PYREX database are given in Table 3. We will hereafter highlight some salient characteristics for each group of measurements.

\section{a. Surface networks}

Surface networks used during PYREX were composed of synoptic stations of the World Weather Watch, secondary French and Spanish networks of automated surface stations, and additional stations specially installed by the participants. With a total number of 200 stations, the PYREX area may be one of the most densely instrumented in the world. All measurements have been quality checked and assembled in a common format for the database. Of special interest are the 15 stations of the CNRM portable network, which were installed at high-elevation
TABLE 1. A list of institutes and agencies involved in PYREX.

\begin{tabular}{|c|c|c|}
\hline Acronym & Institute & Affiliation \\
\hline \multicolumn{3}{|l|}{ France } \\
\hline CETP & $\begin{array}{l}\text { Centre d'Etude des Environnements } \\
\text { Terrestre et Planétaires }\end{array}$ & CNRS \\
\hline CNES & Centre National d'Etudes Spatiales & \\
\hline CNRM & $\begin{array}{l}\text { Centre National de Recherches } \\
\text { Météorologiques }\end{array}$ & $\begin{array}{l}\text { Météo-France } \\
\text { and CNRS }\end{array}$ \\
\hline CNRS & $\begin{array}{l}\text { Centre National de la Recherche } \\
\text { Scientifique }\end{array}$ & \\
\hline $\mathrm{EDF}$ & Electricité de France & \\
\hline INSU & $\begin{array}{l}\text { Institut National des Sciences } \\
\text { de l'Univers }\end{array}$ & CNRS \\
\hline LA & Laboratoire d'Aérologie & CNRS \\
\hline LAMP & Laboratoire de Météorologie Physique & CNRS \\
\hline LMD & $\begin{array}{l}\text { Laboratoire de Météorologie } \\
\text { Dynamique }\end{array}$ & CNRS \\
\hline LSEET & $\begin{array}{l}\text { Laboratoire des Sondages } \\
\text { Electromagnétiques de } \\
\text { l'Environnement Terrestre }\end{array}$ & CNRS \\
\hline Météo-France & French Weather Service & \\
\hline SA & Service d'Aéronomie & CNRS \\
\hline FFVV & Fédération Française de Vol à Voile & \\
\hline \multicolumn{3}{|l|}{ Spain } \\
\hline INM & Instituto Nacional de Meteorología & \\
\hline \multicolumn{3}{|l|}{ Germany } \\
\hline DLR & $\begin{array}{l}\text { Deutsche Luft aud Raum } \\
\text { Forschungsanstalt }\end{array}$ & \\
\hline
\end{tabular}

sites across the range to measure the mountain drag (see section 3a). Besides pressure, these stations reported wind, temperature, and humidity, and exhibited strong Foehn effects (up to $9^{\circ} \mathrm{C}$ difference in temperature and $60 \%$ difference in relative humidity between the two sides of the range in case of meridional flow). 


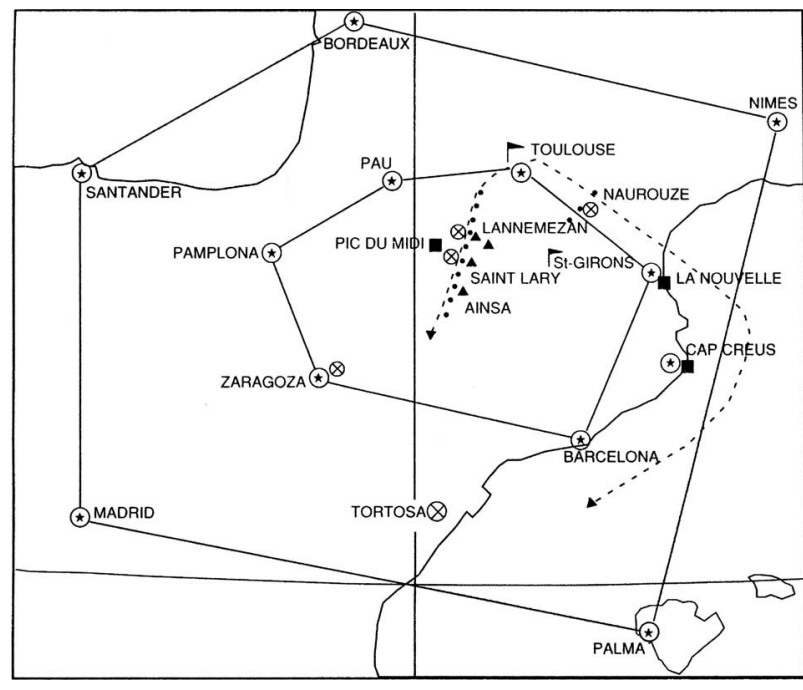

FIG. 1. An overview of the ground network during the field phase. Symbols represent the following: encircled star: soundings; encircled " $x$ ": sodars; solid circle: microbarographs; triangle: profiler; square: site for release of constant level balloons; flag: operation centers for aircraft and gliders.

\section{b. Sodars}

Wind measurements throughout the planetary boundary layer were continuously acquired by four sodars at points of maximum strength of regional winds (INM sodar in Saragoza, EDF sodar in Naurouze) or of special interest for the mountain-induced flow: the EDF sodar in Saint-Lary (central Pyrénées) made measurements from a location at 2300-m altitude just below the main mountain wave; the CETP sodar in Lannemezan (northern foothills) documented return flow generated by lee vortices. It was also used to evaluate the friction velocity (Kotroni and Mazaudier 1993).

\section{c. Soundings}

Operational sounding sites of the area are Madrid, Santander, Palma, Nîmes, and Bordeaux. During IOPs, the frequency of soundings at those sites was increased to four per day. Additional sites were equipped at Barcelona, Pamplona, Zaragoza, Toulouse, La Nouvelle, Cape Creus, and Pau for the duration of the experiment. The PYREX database contains some 730 soundings, most of them with a vertical resolution of about $50 \mathrm{~m}$.

\section{d. Profilers}

Three sites across the range were equipped with profilers of the CNRS-Météo-France "Portable Profilers Research Network" (Petitdidier et al. 1990): the LAMP 72-MHz VHF profiler in Ainsa (Spanish foothills), the

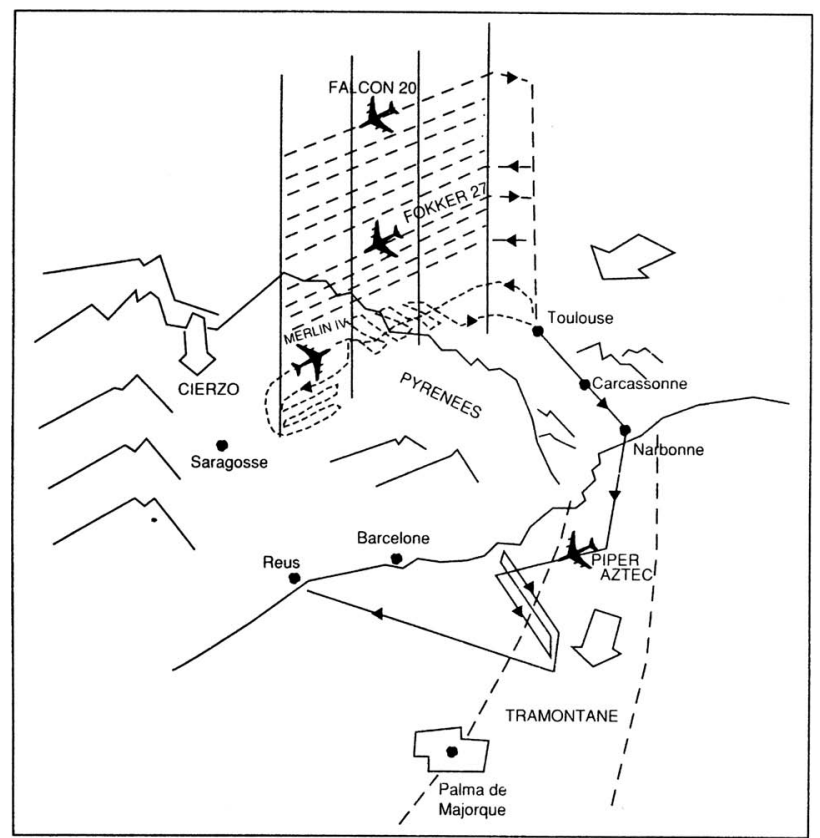

FIG. 2. An example of coordinated flights during a wave IOP with northerly synoptic flow.

CNRM 45-MHz VHF profiler in Saint-Lary (about center of the range), and finally the CETP 961-MHz UHF profiler and the LSEET $45-\mathrm{MHz}$ VHF profiler in Lannemezan (French foothills). Due to the importance of the ground clutter in this mountainous area, some special procedures were developed to quality check the data, and the database contains a quality code for each piece of data. The continuous measurements by VHF profilers allowed detection of nonstationary aspects of the lee waves, such as the time evolution of the vertical velocity, a topic of much current interest. In the case of northerly flow, the high resolution, time continuity, and low range of the UHF in Lannemezan was also ideally suited to document the height of the separation between the layer of blocked flow and the flow going over the mountain. In the case of southerly flow, it allowed measurement of the depth of the lee vortex.

\section{e. Constant level balloons}

A fleet of constant level balloons developed by LA (Benech et al. 1987) was released from three different sites: the Pic du Midi (one of the main summits of central Pyrénées), Cape Creus, and La Nouvelle (both on the Mediterranean coast). The quasi-Lagrangian view of the flow at several altitudes supplied by these tracers is believed of unprecedented quality, with some cases of low-level trajectories longer than $300 \mathrm{~km}$. This provided a severe test for mesoscale numerical models. 


\section{f. Aircraft measurements}

Four research aircraft were available for PYREX: the DLR Falcon 20, the Fokker 27 of the French atmospheric research agencies, the Merlin IV, and the Piper Aztec of MétéoFrance. The first three have a capacity for turbulence measurements.

An example of coordinated flight patterns during wave situations is shown in Fig. 2. While the Falcon and the Fokker were making fairly classic traverses at constant pressure, the Merlin was documenting the orographic boundary layer at altitudes as low as reasonably possible, given safety considerations. These flights give access to the turbulent wake of the range and represent a unique piece of data. They also allow investigation of how the flow changes gradually from $3 \mathrm{D}$ at low levels to quasi-2D at higher levels. Finally, the Piper was measuring the intensity of the regional winds. Thus, simultaneous measurements were made above and around the mountain, in order to obtain the best possible view of the flow morphology in the context of recent theoretical questions on orographic flows.

In other cases, three aircraft made simultaneous flights in the regional winds, in order to document precisely the horizontal and vertical extension of the wind tube and the turbulent momentum fluxes (Fig. 3).

The Fokker was carrying the LEANDRE lidar (Pelon et al. 1990) on all flights. This could measure both at nadir and zenith and gave a wealth of informations on the PBL height and the position of the clouds. Figure 4 is a good example of insight on a wave system obtained through this instrument.
TABLE 2. List of IOPs and operations.

\begin{tabular}{|c|c|c|c|c|}
\hline IOP & Duration & $\begin{array}{l}\text { Syn. } \\
\text { flow }\end{array}$ & Operations & Comments \\
\hline \multirow[t]{3}{*}{1} & $4-5$ Oct & North & 1 Piper flight, Tramontana & \\
\hline & & & 1 Merlin flight, Tramontana & \\
\hline & & & Balloons, Port la Nouvelle & \\
\hline \multirow[t]{8}{*}{2} & $11-14$ Oct & South & 2 Piper flights, Autan & \\
\hline & & & 1 Fokker flight, Autan & \\
\hline & & & 1 Merlin flight, Autan & \\
\hline & & South & 1 Fokker central transect flight & \\
\hline & & & 1 Merlin central transect flight & \\
\hline & & & Balloons, Pic du Midi & \\
\hline & & & Balloons, Cap Creus & \\
\hline & & & Sailplanes & \\
\hline \multirow[t]{6}{*}{3} & $14-15$ Oct & South & 1 Piper flight, Autan & \multirow{6}{*}{$\begin{array}{l}\text { Best case of lee } \\
\text { waves from } \\
\text { south }\end{array}$} \\
\hline & & & 1 Merlin central transect flight & \\
\hline & & & 1 Fokker central transect flight & \\
\hline & & & 1 Falcon central transect flight & \\
\hline & & & Balloons, Pic du Midi & \\
\hline & & & Sailplanes & \\
\hline \multirow[t]{6}{*}{4} & $20-21$ Oct & South & 1 Piper flight, Autan & \\
\hline & & & 1 Merlin central transect flight & \\
\hline & & & 1 Fokker central transect flight & \\
\hline & & & Balloons, Pic du Midi & \\
\hline & & & Balloons, Cap Creus & \\
\hline & & & Sailplanes & \\
\hline
\end{tabular}

On some occasions, the PYREX research aircraft were joined by several gliders of the FFVV. Although purely qualitative, the information acquired by these additional media confirmed in general the quasi-2D aspect of the lee wave system (Benech et al. 1994). 
TABLE 2. Continued.

\begin{tabular}{|c|c|c|c|c|}
\hline IOP & Duration & $\begin{array}{l}\text { Syn. } \\
\text { flow }\end{array}$ & Operations & Comments \\
\hline \multirow[t]{3}{*}{5} & $25-26 \mathrm{Oct}$ & South & 1 Piper flight, Autan & \multirow{3}{*}{$\begin{array}{l}\text { Front crossing } \\
\text { the area during } \\
\text { operations }\end{array}$} \\
\hline & & & 1 short Merlin, flight & \\
\hline & & & Balloons, Cap Creus & \\
\hline \multirow[t]{4}{*}{6} & $3-5$ Nov & North & 1 Piper flight, Tramontana & \multirow{4}{*}{$\begin{array}{l}\text { Tramontana } \\
\text { weakens } \\
\text { during second } \\
\text { day }\end{array}$} \\
\hline & & & 2 Merlin flights, Tramontana & \\
\hline & & & 2 Fokker flights, Tramontana & \\
\hline & & & Balloons, Cap Creus & \\
\hline \multirow[t]{4}{*}{7} & 6-7 Nov & South & 1 Piper flight, Autan & \\
\hline & & & 1 Merlin flight, Autan & \\
\hline & & & 1 Fokker flight, Autan & \\
\hline & & & Balloons, Cap Creus & \\
\hline \multirow[t]{3}{*}{8} & 11-12 Nov & North & 1 Piper flight, Cierzo & \\
\hline & & & 1 Merlin central transect flight & \\
\hline & & & Balloons, Cap Creus & \\
\hline \multirow[t]{5}{*}{9} & $14-16$ Nov & North & 2 Piper flights, Tramontana & \multirow{5}{*}{ 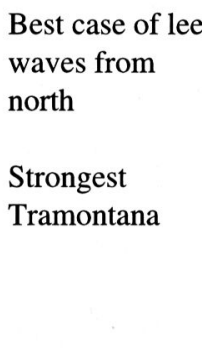 } \\
\hline & & & 3 Merlin central transect flights & \\
\hline & & & 3 Fokker central transect flights & \\
\hline & & & 3 Falcon central transect flights & \\
\hline & & & Balloons, Port la Nouvelle & \\
\hline \multirow[t]{4}{*}{10} & $28-30 \mathrm{Nov}$ & North & 2 Piper flights, Cierzo & \multirow{4}{*}{$\begin{array}{l}\text { Best Cierzo on } \\
\text { second day }\end{array}$} \\
\hline & & & 2 Merlin flights, Cierzo & \\
\hline & & & 2 Fokker flights, Cierzo & \\
\hline & & & Balloons, Port la Nouvelle & \\
\hline
\end{tabular}

sure measurements along the main cross section is described in detail by Bessemoulin et al. (1993). The drag evolution during the 2 months of the field phase is shown in Fig. 5. We believe it is the most precise determination of this quantity ever achieved. Indeed, (i) the result is not sensitive to the inclusion or removal of any given station and (ii) the drag is extremely well correlated to the difference between the sea level pressures at Pau (French side) and Zaragoza (Spanish side), two stations that have not been used in the computation. This correlation may be predicted by a very simple hypothesis that the pressure field varies linearly in space, but it would be impossible to determine the ratio between the two quantities without making the experiment. One important consequence of Fig. 5 is that the pressure drag in the central Pyrenean section can now be accurately estimated from the operational measurements in Pau and Zaragoza only. This could be useful in future field projects or to evaluate a long term trend.

Another interesting finding is the relatively good prediction of the drag by the $2 \mathrm{D}$ linear formula $\mathrm{D}=\rho U N h^{2}$ (where $\rho, U$, $N$, and $h$ stand for the low-level air density, normal velocity, static stability, and the mountain maximum height, respectively). Such a good agreement was not expected since the Froude number $(U / N h)$ of the incident flow is generally quite small. Some

\section{Main experimental results}

\section{a. Measurement and interpretation of the mountain pressure drag}

The computation of the pressure drag from the pres- recent numerical work on idealized cases by Olafsson and Bougeault (1997) showed that the cooperative effect of rotation and surface friction results in drag values surprisingly close to the linear theory for a large range of Froude numbers. This may explain the 


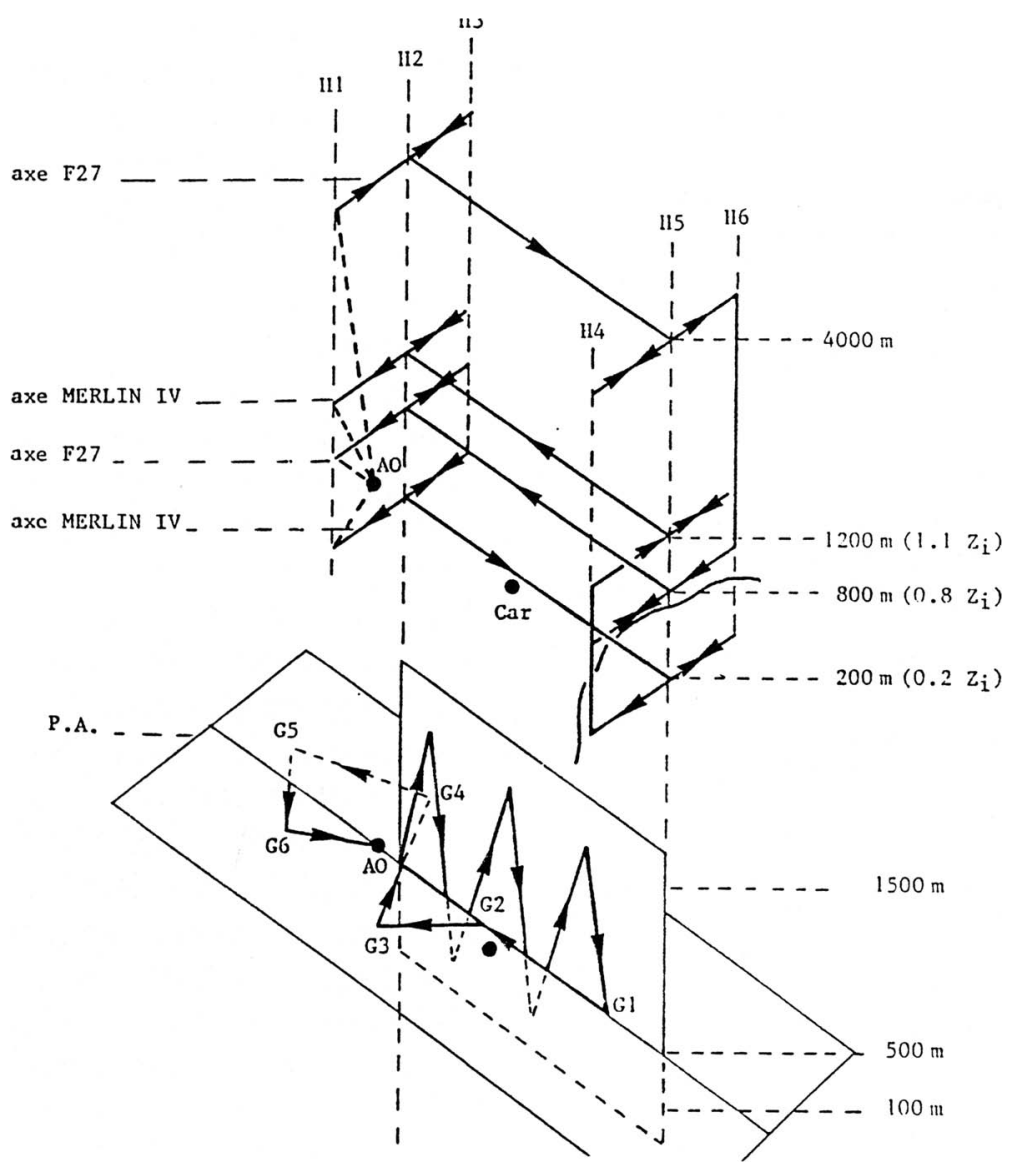

FIG. 3. An example of coordinated flights during an IOP devoted to regional wind (case of the Autan). These flights were made over rather flat terrain, and the elevations are given in meters above ground level (AGL).

energy and its dissipation. The ratio between these two quantities is of high interest for the calibration of turbulence parameterizations. It was shown to be comparable to that found in convective boundary layers, which gives some hope that the parameterization schemes developed for the PBL can also do a reasonable work for orographic flows.

The lee waves were also studied by Benech et al. (1994), and Tannhauser and Attié (1995) with linear models. The nonstationary aspects of the flow were addressed by Caccia et al. (1997).

\section{c. The wind around the range}

The Tramontana was studied in detail by Campins et al. (1995). They showed that the direction of the wind varies from case to case, dependent on the synoptic-scale wind direction. The wind speed appears very well correlated to the pressure drag, which reinforces the idea that Tramontana is a direct consequence of the orographic pressure dipole. A diagnostic study of the airmass momentum budget showed that the acceleration between the foothills and the sea is consistent with the pressure gradient. Once it has arrived over the sea, the air mass acquires an inertial behav-

PYREX observations. Other details on the drag interpretation may be found in Genoves et al. (1994).

\section{b. Experimental studies of mountain waves}

The aircraft observations of mountain waves in the central cross section have been analyzed by Attié (1994) and Attié et al. (1996). He used a spectral decomposition based on the wavelet theory to isolate the contributions of three different spatial scales. At the mesobeta scale, the standing orographic wave was shown to exhibit most of the features expected from the linear theory. This structure was also reproduced satisfactorily by several numerical models. At the mesogamma scale, the lee waves and the associated fluxes of heat and momentum were isolated. Finally, at the microscale, all the characteristics of turbulence were mapped in the vertical cross section. A composite analysis of the various cases allowed mapping of the structure of the mountain wake (see examples in Fig. 6), with emphasis put on the turbulence kinetic ior, turning regularly to the right in the absence of a well-defined pressure gradient over the Mediterranean. This was also found in a numerical study by Salvayre (1993).

The most systematic investigation of the wind around the range is the Ph.D. thesis of Koffi (1994; see also B. Benech et al. 1997, manuscript submitted to J. Appl. Meteor.; E. Koffi et al. 1997, manuscript submitted to J. Appl. Meteor.). Among many interesting results, he found that the surface wind velocities on both sides of the range are extremely well correlated. This lends credit to the idea of the airflow adapting dynamically to the presence of the range with systematic response depending mainly on the synoptic flow. He also compared the observed wind with the prediction of a linear model of the flow around an elliptic obstacle (including the effects of rotation and incidence angle). With this model, he was able to reproduce many observed features, an example of which is given in Fig. 7. Thus, the usefulness of 
the linear theory is again demonstrated, even in those cases of low Froude number flows.

The height of the blocking area upstream of the range was analyzed by Petitdidier et al. (1994). This study showed that the formula $h_{\mathrm{b}}=h(1-$ U/Nh) proposed by Hunt and Snyder (1980) for the height of the blocking $h_{\mathrm{b}}$ applies quite well in our case. The vertical extension of the lee vortices was also studied by Petitdidier (1996).

\section{d. Turbulence and organized \\ structures in the boundary layers close to the range}

A large number of flights allowed documentation of the turbulent boundary layers associated with the regional winds, both in situ and with the airborne lidar. The Tramontana flights were analyzed by Flamant and Pelon (1996). They interpreted the development of the marine boundary layer with a mixed layer model. The combined increase of surface wind and heat flux at increasing fetch leads to a regular increase of the PBL height, modulated by the mesoscale subsidence induced by the mountain. On the other hand, the shelter effect of the Pyrénées was clearly visible in some places, with areas of lower PBL height.

In the Tramontana flow, the combination of strong winds and surface heat flux results in the formation of rolls, sometimes showing up on satellite pictures as cloud streets. These structures are visible both in the aircraft in situ measurements and on the lidar detection of the PBL height. A good consistency was found between the two types of measurements (Bougeault et al. 1993b). A detailed study of the thickness of the entrainment zone by lidar observation was undertaken by C. Flamant et al. (1996, manuscript submitted to Bound.-Layer Meteor.).

The Tramontana flights also comprise long tracks at very low height (about $40 \mathrm{~m}$ above the sea), where turbulence measurements were taken. This allows for the determination of the bulk transfer coefficients, and the corresponding value of the Charnock constant was retrieved by Hedde and Durand (1994). The fea-
TABLE 3. Some characteristics of measurements retained in the PYREX database. This is a very general overview, as precise characteristics may vary depending on the instrument. Resolutions are based on IOP data. In some cases, data also exist outside IOPs, with similar or lower resolutions. More detailed information may be found in Bougeault et al. (1993).

\begin{tabular}{|c|c|c|}
\hline Facility & Parameters & $\begin{array}{l}\text { Horizontal resolution, } \\
\text { vertical resolution, } \\
\text { range, time resolution }\end{array}$ \\
\hline $\begin{array}{l}\text { Surface } \\
\text { networks }\end{array}$ & $\begin{array}{l}\text { Wind, temperature, humidity, } \\
\text { weather }\end{array}$ & $\begin{array}{l}30 \mathrm{~km}, \\
10 \mathrm{~min} \text { to } 1 \mathrm{~h}\end{array}$ \\
\hline Sodars & Wind ( 3 components) & $\begin{array}{l}50 \mathrm{~m}, 15 \mathrm{~min} \\
\text { from ground to } 500 \mathrm{~m}\end{array}$ \\
\hline Soundings & $\begin{array}{l}\text { Pressure, altitude, wind, } \\
\text { temperature, humidity }\end{array}$ & $\begin{array}{l}200 \mathrm{~km}, 50 \mathrm{~m}, 6 \mathrm{~h} \\
\text { from ground to about } \\
100 \mathrm{hPa}\end{array}$ \\
\hline VHF profilers & Wind ( 3 components) & $\begin{array}{l}375-2250 \mathrm{~m}, \\
12 \mathrm{~min}, \text { from } 1000 \\
\text { to } 15000 \mathrm{~m}\end{array}$ \\
\hline UHF profilers & Wind ( 3 components) & $\begin{array}{l}150 \mathrm{~m}, 12 \mathrm{~min} \\
\text { from } 200 \text { to } 5000 \mathrm{~m}\end{array}$ \\
\hline $\begin{array}{l}\text { Constant level } \\
\text { balloons }\end{array}$ & $\begin{array}{l}\text { Pressure, temperature, wind, } \\
\text { humidity, position along } \\
\text { trajectory }\end{array}$ & $10 \mathrm{~s}$ \\
\hline \multirow[t]{2}{*}{ Aircraft } & $\begin{array}{l}\text { Position, pressure, altitude, } \\
\text { wind, temperature, } \\
\text { humidity }\end{array}$ & $\begin{array}{l}10 \mathrm{~s} \\
\text { (1 s for wave flights) }\end{array}$ \\
\hline & Turbulent fluxes & By $20-\mathrm{km}$ segments \\
\hline Airborne lidar & Reflectivity & $\begin{array}{l}100 \mathrm{~m}, 1 \mathrm{~s} \\
\text { from aircraft to } \\
\text { ground or tropopause }\end{array}$ \\
\hline
\end{tabular}

sibility of measuring the turbulent fluctuations of moisture by a capacitive method was studied by Durand et al. (1995). Finally, Dupont et al. (1994) completed the calibration of the LEANDRE lidar with these data.

\section{Main modeling results}

\section{a. Hydrostatic models}

Before the experiment, mesobeta-scale models were used to anticipate the amplitude of the orographic perturbation and to verify the validity of many 


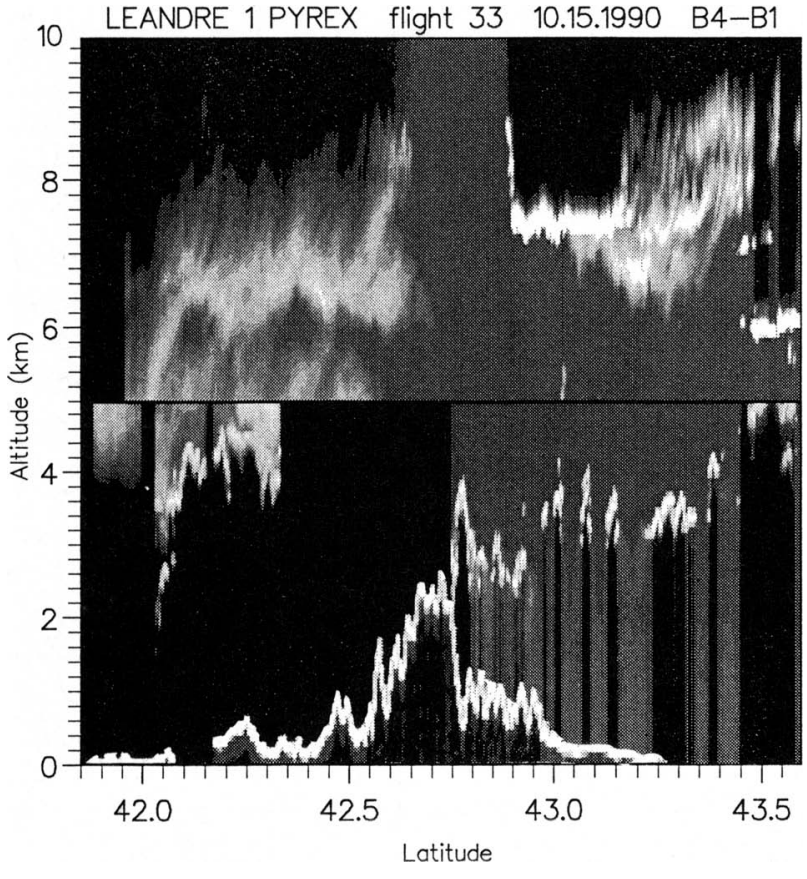

FIG. 4. Vertical cross section of the wave obtained by combining zenith and nadir shots of the LEANDRE lidar on 15 October 1990. The ground echo and the clouds are visible as white pixels. The picture shows an altrostratus layer at $6-8 \mathrm{~km}$, temporarily interrupted by the Foehn clearance, and several altocumulus clouds marking the top of lee waves, around $4 \mathrm{~km}$ altitude.

experimental concepts (e.g., Stein 1992). Shortly after the experiment, all soundings and surface measurements were used to produce a reference reanalysis of the IOPs, using the data assimilation suite of the operational limited area model of Météo-France. These analyses were used to provide initial and boundary conditions for the mesoscale models in many works described hereafter. Later on, the European Centre for Medium-Range Weather Forecasts (ECMWF) also produced a reanalysis of the 2-month experimental period with their T213 model (Lott

1995). This reanalysis is available on the Meteorological Archiving and Retrieval System (MARS).

Most IOPs were simulated at CNRM with a research version of the PERIDOT limited area model, at $10 \mathrm{~km}$ horizontal resolution. Examples of such studies may be found in Bougeault et al. (1992), Bougeault et al. (1993b), Salvayre (1993), and Masson and Bougeault (1996b). These studies demonstrated the correct behavior of the model and the predictability of many mesoscale features, such as the shape and intensity of the mountain wave and the strength of the regional winds. In some cases, orographic lee vortices could also be simulated, in fair agreement with the observation. A special emphasis in these studies was put on the comparison of simulated turbulent fluxes with the corresponding observations, as we wanted to ascertain the capacity of our turbulence parameterization (Bougeault and Lacarrère 1989) in regions of complex terrain. The results were in general quite encouraging. The pressure drag was also reproduced with high accuracy, as was the wave momentum flux. This lead to the conclusion that the model gives a sufficiently accurate picture of the regional momentum budget to allow for the investigation described in section $5 b$.

The new model, ALADIN, recently developed by an international team of East European scientists hosted by Météo-France, was also tested against PYREX observations. It succeeded in reproducing the above-mentioned features. One of the main results was the simulation of the lee vortices observed during IOP 3, as shown in Fig. 8, from von der Emde and Bougeault (1997).

The INM limited-area model was used by GarciaMoya et al. (1992) to simulate some PYREX flows. It showed great improvement when the resolution was increased from $0.91^{\circ}$ to $0.455^{\circ}$, but further increase in the resolution did not continue this trend. The data assimilation system was applied to the PYREX data by Navascues (1992).

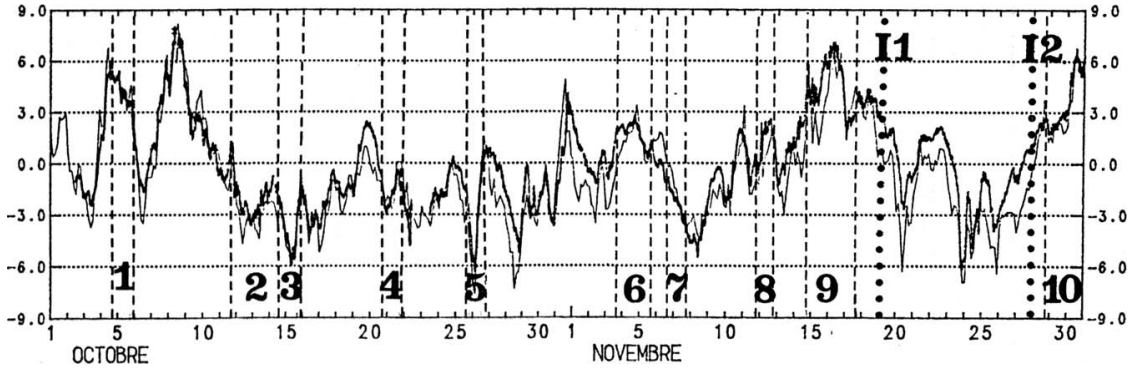

FIG. 5. The time series of the values of the pressure drag in the central part of the range, from Bessemoulin et al. (1993). Numbers indicate the IOPs and the intercomparison flights.
Most IOPs were also simulated with the SALSA model at LA. A wealth of comparisons with observations demonstrated the correct behavior of the model. Among other scientific results, these experiments allowed new insight into the dynamics of the transition between flow over the mountain and 
flow around the mountain. For instance, Georgelin et al. (1996) showed that the formation of an upslope wind (due to thermal effect) on the upstream (Spanish) slope decreases the amount of air that flows around the mountain and, therefore, decreases the intensity of the Autan wind (in France). On the contrary, during the night, the Autan increases in relation with the upstream blocking. Georgelin and Richard (1996) studied similar effects for the case of northerly synoptic flow, pointing also to the importance of thermal effects. These studies bring experimental support to the recent work by Reisner and Smolarkiewicz (1994).

The time evolution of the observed drag during periods of several days has been reproduced by Elkhalfi et al. (1995), with a two-dimensional version of the SALSA model, forced by the observed upstream soundings, with rotation neglected. Although the result was very encouraging, this methodology seems questionable. Indeed, when comparing two- and threedimensional simulations obtained with the same initial conditions, Bougeault (1994) found large differences when the 2D simulations do not include the geostrophic forcing.

The sensitivity of mountain wave simulations to Coriolis effects has been confirmed in a full 3D study by Olafsson and Bougeault (1996).

\section{b. Nonhydrostatic models}

Lee waves observed during several IOPs have formed an ideal subject of study for nonhydrostatic models. A quantitative simulation of lee waves excited by a high mountain range like the Pyrénées is known to be a difficult subject, because of the sensitivity of the results to small variations in the upstream profiles and to the mountain shape and roughness. Elkhalfi and
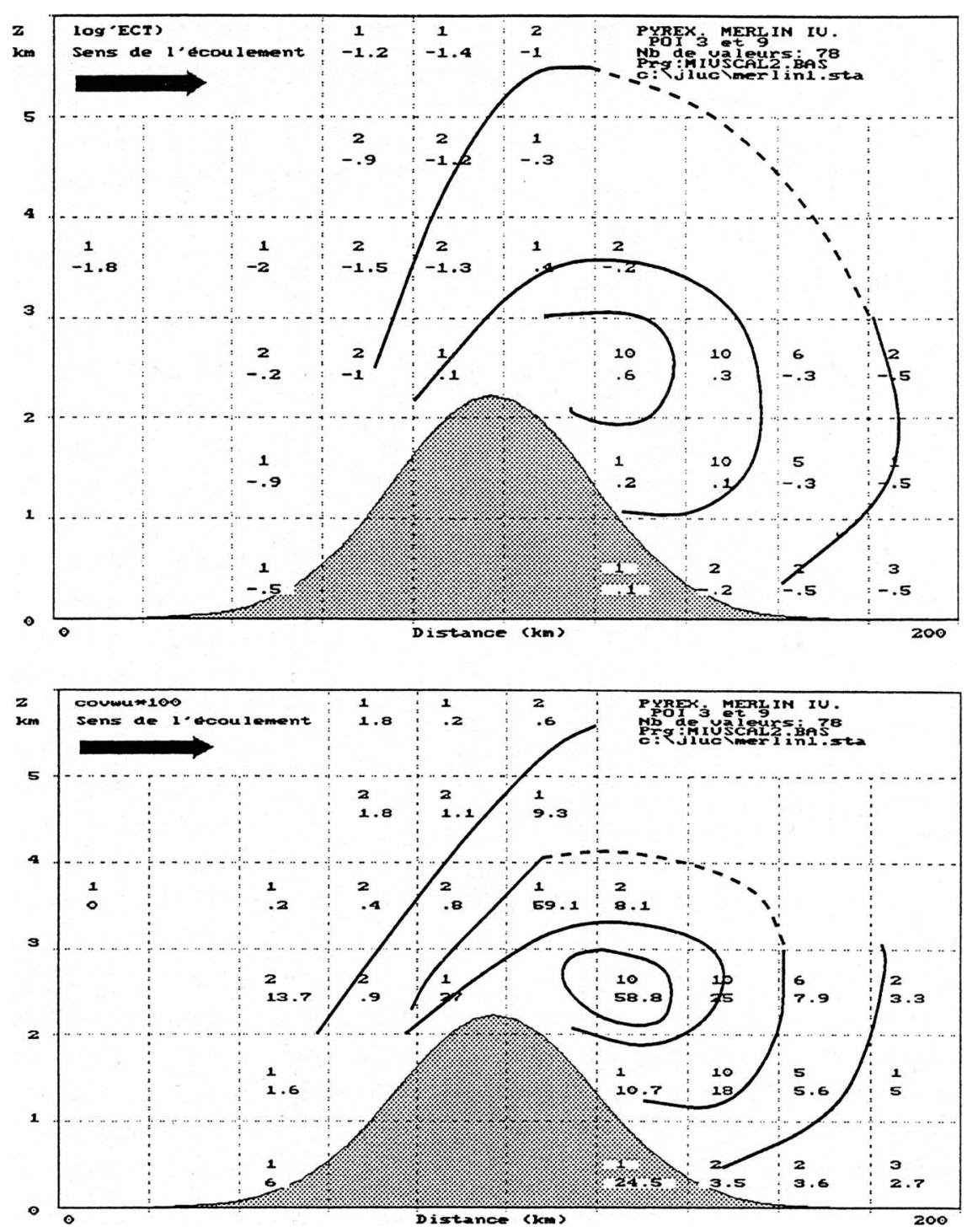

FIG. 6. Composite cross section of the mountain wake obtained by Attié (1994). The top panel shows the decimal logarithm of the turbulent kinetic energy $\left(0\right.$ stands for $1 \mathrm{~m}^{2} \mathrm{~s}^{-2}, 1$ stands for $10 \mathrm{~m}^{2} \mathrm{~s}^{-2}$, aso). The bottom panel shows the flux of normal momentum (in $10^{-2} \mathrm{~m}^{2} \mathrm{~s}^{-2}$ ). The first number in each box is the number of flight tracks used to elaborate the composite.
Carissimo (1993) have simulated the lee waves of the IOP 3 with the MERCURE model of EDF. They found an excellent agreement with the observations of wavelength, amplitude, and momentum flux (Fig. 9). Only the phase of the waves was not reproduced accurately. They also showed that the model is able to discriminate between periods of intense and weak or nonexistant lee waves.

Later work led, however, to questioning of the significance of this early result. In several studies, it was not possible to reproduce the good agreement between the observed and simulated momentum fluxes, which 


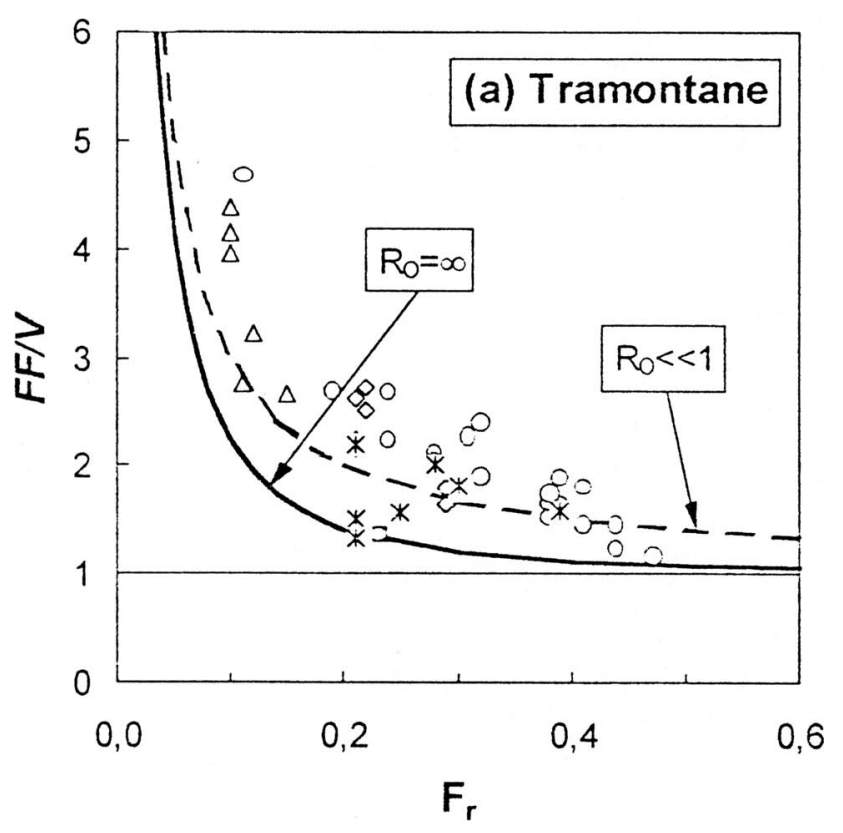

FIG. 7. The Tramontana wind speed, normalized by the wind speed of the incident synoptic flow, as function of the Froude number Fr of the incident flow. Also shown are the predictions of a linear model of the flow around the range, both with (dashed line) and without (solid line) the Coriolis force. From B. Benech et al. (1997, manuscript submitted to J. Appl. Meteor.).

may suggest that the former result is a consequence of transient adaptation of the model. Satomura and Bougeault (1994) obtained a momentum flux constant with altitude, which one would indeed expect for the stationary result of a two-dimensional model. The first three-dimensional lee wave simulation of PYREX was performed by Broad (1996). The agreement with observations was good for the wave intensity but rather poor for the wave length and the momentum flux. This study also showed a large variability of the momen- tum flux in the direction parallel to the crest line. Recently, Satomura (1996) showed that the linear result for a 3D, stationary mountain wave over an elliptical mountain exhibits decrease with height of the momentum flux, as measured during PYREX. This strongly suggests that the observations should be considered as influenced by $3 \mathrm{D}$ effects (at the scale of the whole range).

A new model under development as a cooperative project between CNRM and LA, Meso-NH, has been recently applied to the simulation of PYREX lee waves. Masson and Bougeault (1996a) present a series of simulations at increasing resolutions $(25,10$, and $2 \mathrm{~km}$ ) demonstrating the good behavior of the model. The last one may represent the most realistic 3D simulation of PYREX lee waves available at time (see Fig. 10). Another notable development is the nonhydrostatic version of the ALADIN model, which has been shown by J. Geleyn and R. Bubnova (1996, manuscript submitted to Ocean Atmos. Dyn.) to reproduce fairly well the PYREX lee waves.

At the end of 1994, the IOP 3 of PYREX was selected as the second "COMPARE" international LAM intercomparison exercise under the auspices of the World Meteorological Organization (WMO). The ECMWF reanalysis of the case was distributed to about 15 participants throughout the world, and the results of the intercomparison have been discussed in a workshop hosted by Météo-France in Toulouse, 35 September 1996. A preliminary result of this exercise is the beneficial effect of high values of the roughness height in mountainous areas, which confirms some of the PYREX findings (see below). On the other hand, many models were unable to reproduce the abovementioned lee vortices.
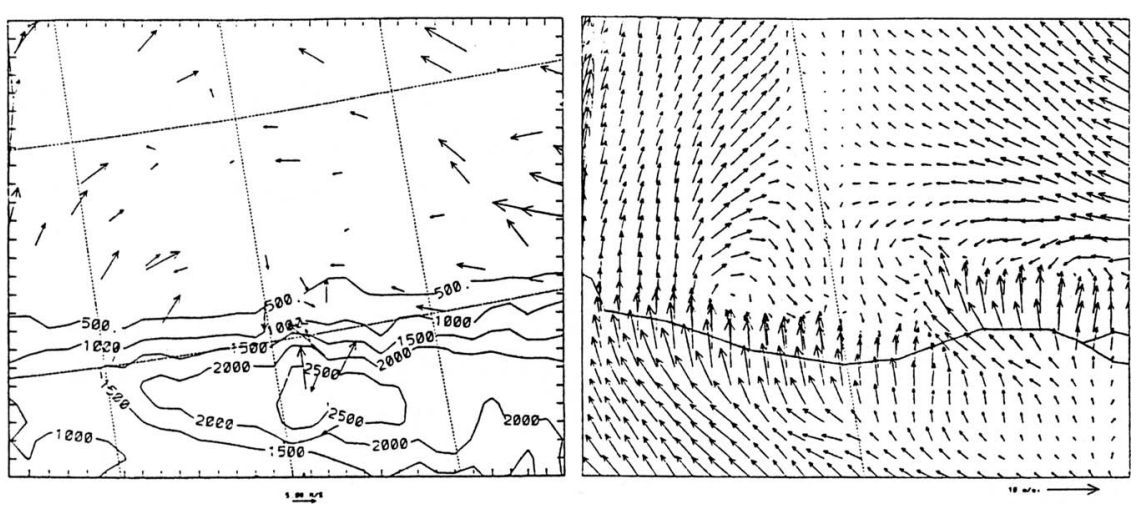

FIG. 8. Observations and simulation by the ALADIN model of lee vortices on 15 October 1990 (from von der Emde and Bougeault 1997).

\section{Improvement of parameterizations for larger-scale models}

One of the main motivations of PYREX was to acquire a dataset that could be used to improve parameterizations of subgrid orography in GCMs and large-scale NWP models. This objective has been reached. Thanks to PYREX data, it has indeed been possible to make progress on the parameteriza- 
tion of orographic roughness and subgrid-scale gravity wave drag.

\section{a. Orographic roughness}

The optimal value of orographic roughness is a subject of theoretical debate and sometimes of purely empirical tuning. In a very convincing paper, Georgelin et al. (1994) applied the proposal of Mason (1988) to the Pyrénées and obtained values of $z_{0}$ of order 10-15 $\mathrm{m}$ in the central Pyrénées. The use of these large values led to a clear improvement in the model results. Not only was the wave intensity reproduced more accurately, but the value of the wind all around the range (even over the sea) became closer to the observations. Following the publication of Georgelin's paper, a similar increase was adopted in the Eta Model of the National Meteorological Center (NMC, renamed the National Centers for Environmental Prediction), and this seems to have improved performance (Mesinger et al. 1996).

This may suggest that many idealized simulations of mountain flow, realized with small surface roughness, overestimate the tendency toward wave breaking. It should be noted that wave breaking in the troposphere was not observed during PYREX. Yet it is often simulated by mesobeta-scale models if the roughness is set to a low value.

\section{b. Subgrid-scale gravity wave drag}

The measurements of pressure drag and wave momentum flux acquired in the central Pyrénées during PYREX allow for an evaluation of this sensitive part of the GCM physics. Early results on the evaluation of current parameterizations of gravity wave drag (GWD) in the light of PYREX data have been discussed by Bougeault et al. (1992). They showed that current schemes were underestimating the GWD by a factor of 4 at least. This was confirmed by Lott (1995), using the ECMWF model. It is, however, a rather difficult problem to decide how much of the drag should be parameterized and how much is actually resolved by any given model, especially since the measurements are representative of the central part of the range only. An original method was developed by Beau and Bougeault (1993) and Beau (1996) to tackle this problem. The various terms of the momentum budget in a reference simulation of mountain flow are first accumulated. By reference simulation, we mean a high-resolution simulation $(10 \mathrm{~km})$ where the total pressure drag and wave momentum flux compare favorably with the available observations. Then the

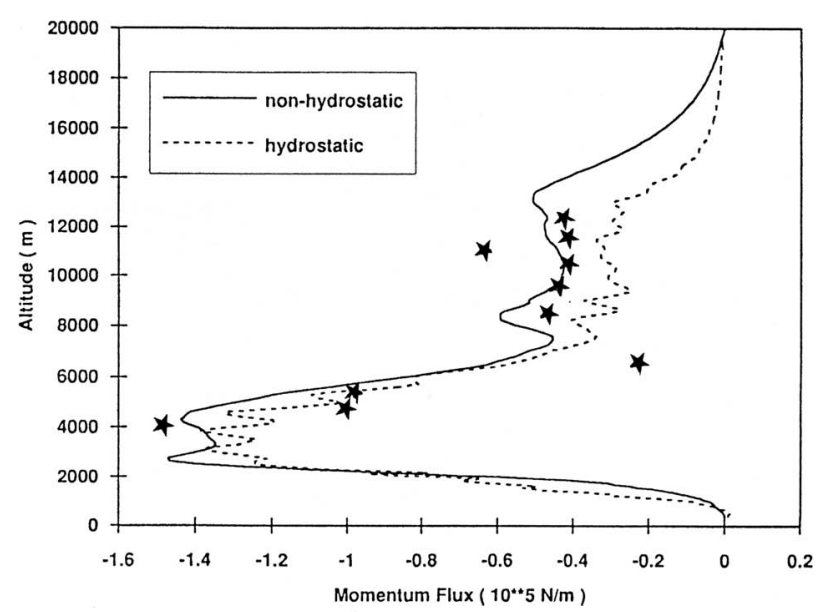

FIG. 9. Flux of momentum measured by the research aircraft on 15 October 1990 and simulated by two versions of the MERCURE model (from Elkhalfi and Carissimo 1993).

simulation is repeated with the model resolution (and orography) degraded to that of current GCM or NWP models $(50$ or $100 \mathrm{~km})$. The terms of the momentum budget are again accumulated. Finally, the term by term difference between the above two quantities are computed. This forms the differential momentum budget. They argue that the GWD parameterizations should reproduce accurately this differential momentum budget. This was confirmed in the following way. The parameterization was tuned in such a way as to fit the differential budget, then introduced in the lowresolution model and run interactively. The momentum budget computed during the new run compares much better with the reference momentum budget than the one of the initial low-resolution experiment. This supports some general concepts of the GWD parameterization, for example, the idea that the feedback of mountain waves on the mean flow is well described at first order by a single term, the vertical divergence of the wave momentum flux. This had been recently questioned by Durran (1995), who showed that the horizontal divergence of the total horizontal flux of momentum becomes nonnegligible when the momentum budget is considered at scales of $100-300 \mathrm{~km}$. The above results suggest that effective GWD parameterizations can nevertheless be formulated without accounting for contributions from the horizontal fluxes of momentum, at least for the range of scales currently used in general circulation models.

However, the simulations also show that the optimal tuning of the parameterization is variable from case to case. This was interpreted as an effect of the variable tendency of the flow to go around the moun- 

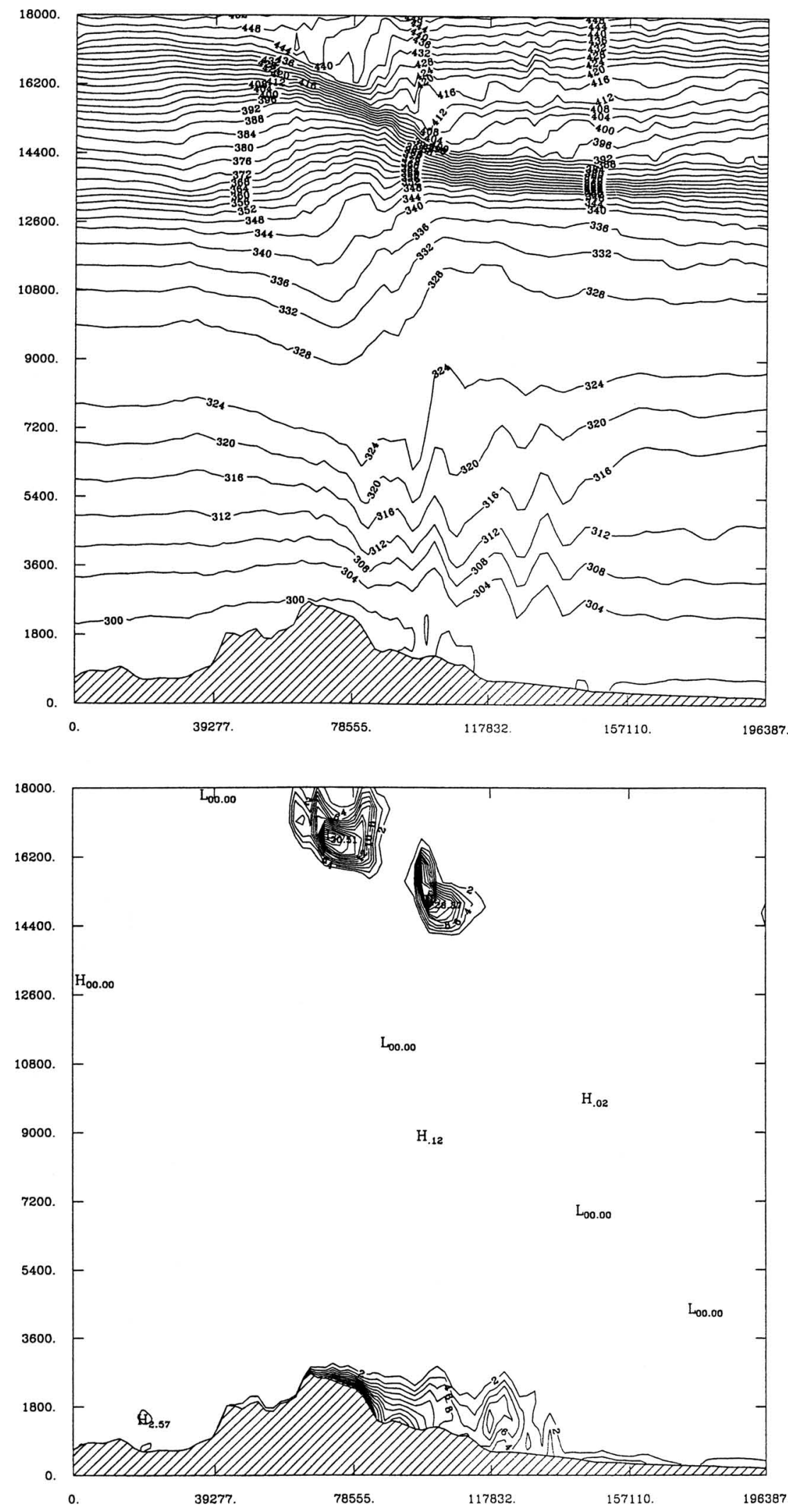

tain rather than over it and calls for an explicit representation of the split flow effects as a function of the Froude number in these parameterizations. This last step was achieved by Lott and Miller (1997), in a recent revision of the ECMWF GWD parameterization. Figure 11, from this study, demonstrates the superiority of the new approach, which has the full benefit of the PYREX data. This parameterization was recently introduced in several other GCMs. Similar work is also presented by Broad (1996) with the U.K. Meteorological Office parameterization.

\section{Conclusions: Some lessons from PYREX}

The high level of interaction between numerical modeling at the mesoscale and the experimental approach is one distinctive characteristic of PYREX. Some of the most important results, such as the confirmation of the benefits of the high values of roughness and the revision of the GWD parameterizations, could only be obtained by a combination of model studies and extensive use of the observations. Indeed, the momentum budget of the atmosphere in an area of complex terrain would be impossible to deduce from the observations only. Numerical

FIG. 10. Results of the Meso-NH model on PYREX IOP3. The upper panel shows potential temperature in the central Pyrenean section, with synoptic flow from south (left) to north (right). The lower panel shows the turbulence kinetic energy, with isolines of $1 \mathrm{~m}^{2} \mathrm{~s}^{-2}$. The wake of the mountain is well visible in the low levels, and the upper maxima trace wave breaking in the lower stratosphere. From Masson and Bougeault (1996a). 


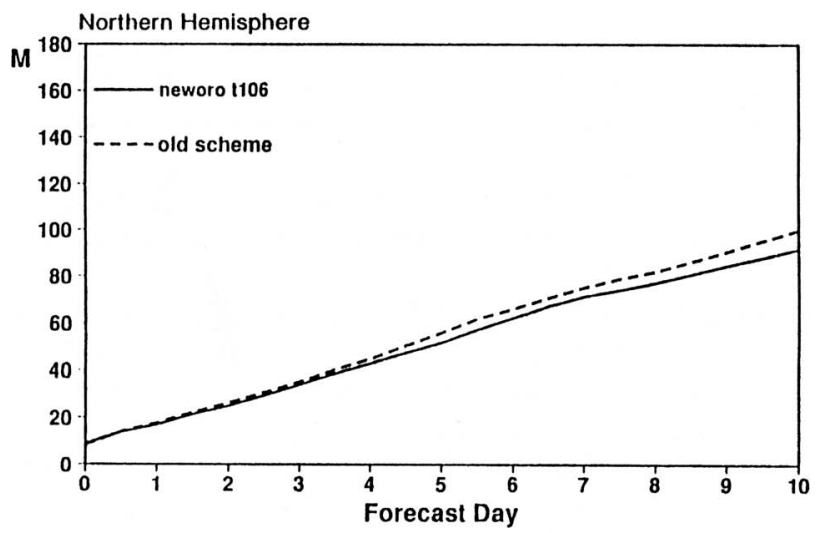

FIG. 11. Improvement of the 500 -hPa rms height error of the ECMWF model, following the revision of the GWD parameterization to take account of PYREX data. From Lott and Miller (1997).

models, conveniently validated by the available observations, are a much more convincing and practical tool to achieve this result.

In general, we found that the mesoscale models perform reasonably well. This justifies optimism regarding the possibility of operationally forecasting the flow in mountainous environment, when computer capacity allows for it.

Another general finding is that the linear theory contains many interesting information to interpret orographic flows, even at the low Froude numbers encountered during this field program.

Finally, we should like to recall that many of the data have actually not yet been analyzed (except for quality checking), as their quantity largely exceeds the possibilities of the institutes involved in this program. The PYREX database has been made public since the beginning of 1993 and is available to any interested scientist upon request. We hope that the present paper will contribute to advertising this opportunity.

Acknowledgments. A list of the funding agencies and of the participating institutes is given in Table 1. Much technical help was also provided by the operational centers of Météo-France and the INM, the Center for Meteorological Aviation of CNRM, the Balloon Department of CNES, and the Technical Division of the CNRS/INSU. We would like to express our sincere appreciation to all the participants to the field phase whose time and efforts have allowed us to realize this successful program. Thanks also to Dale Durran for interesting discussions and to an anonymous referee for careful editing of this manuscript.

\section{References}

Attié, J. L., 1994: Etude d'un ecoulement près d'un relief à partir de moyens aéroportés (expérience PYREX). Ph.D. disserta- tion, Université Paul Sabatier, 196 pp.

—, A. Druilhet, P. Durand, and B. Benech, 1996: Two-dimensional structure of mountain wave events observed by aircraft during the PYREX experiment. Ann. Geophys., in press.

Beau, I., 1996: Validation de paramétrisation des ondes de gravité à l'aide des données PYREX. Ph.D. dissertation, Université Paul Sabatier, 350 pp.

- , and P. Bougeault, 1993: Evaluation des paramétrisations de l'effet orographique sous-maille à l'aide des observations PYREX. Atelier de Modélisation de l'Atmosphére, CNRM, 173-182.

Benech, B., A. Druilhet, R. Cordesse, B. Dartiguelongue, J. Fournet-Fayard, J. C. Mesnager, P. Durand, and A. Malaterre, 1987: Un dispositif expérimental utilisant des ballons plafonnants pour l'étude de la couche limite atmosphérique. Adv. Space. Res., 7, 77-83.

- J. L. Attié, A. Blanchard, P. Bougeault, P. Cazaudarré, A. Druilhet, P. Durand, E. Koffi, P. Prudhomme, and D. S. Tannhauser, 1994: Observation of lee waves above the Pyrénées (French Spanish PYREX experiment). Tech. Soaring, 18, 7-12.

Bessemoulin, P., P. Bougeault, A. Genoves, A. Jansa Clar, and D. Puech, 1993: Mountain pressure drag during PYREX. Contrib. Atmos. Phys., 66, 305-325.

Bougeault, P., 1994: Are 2D simulations a good approximation of orographic flows? An example from PYREX. Preprints, Sixth Conf. on Mesoscale Processes, Portland, OR, Amer. Meteor. Soc., 467-470.

_ and P. Lacarrère, 1989: Parameterization of orographyinduced turbulence in a meso-beta-scale model. Mon. Wea. Rev., 117, 1872-1890.

—, A. Jansa Clar, B. Benech, B. Carissimo, J. Pelon, and E. Richard, 1990: Momentum budget over the Pyrenees: The PYREX experiment. Bull. Amer. Meteor. Soc., 71, 806818.

—, I. Beau, and J. Stein, 1992: Validation of meteorological models and parameterizations with observations of the PYREX field experiment. Validation of models over Europe, Reading, United Kingdom, European Centre for MediumRange Weather Forecasts, 247-285.

_, R. Benoit, and G. Jaubert, 1993a: The PYREX data base. Météo-France Note 9, CNRM/GMME, 135 pp. Available from CNRM, 42, avenue Gustave Coriolis, 31057 Toulouse Cedex, France.]

_ , and Coauthors, 1993b: The atmospheric momentum budget over a major mountain range: First results of the PYREX field program. Ann. Geophys., 11, 395-418.

- B. Benech, P. Bessemoulin, B. Carissimo, A. Jansa, J. Pelon, M. Petitdidier, and E. Richard, 1996: Programme PYREX-Rapport scientifique final. Météo-France Note 41, CNRM/GMME, 43 pp. [Available from CNRM, 42, avenue Gustave Coriolis, 31057 Toulouse Cedex, France.]

Broad, A. S., 1996: High resolution numerical model integrations to validate gravity wave drag parameterization schemes: A case study. Quart. J. Roy. Meteor. Soc., 122, 1625-1654.

Caccia, J. L., B. Benech, and V. Klaus, 1997: Space-time description of nonstationnary trapped lee wave using ST radars and airborne instruments during PYREX experiment. J. Atmos. Sci., in press.

Campins, J., A. Jansa, B. Benech, E. Koffi, and P. Bessemoulin, 1995: Pyrex observation and model diagnosis of the Tramontane wind. Meteor. Atmos. Phys., 56, 209-228. 
Dupont, E., J. Pelon, and C. Flamant, 1994: Study of the moist convective boundary layer structure by backscattering lidar. Bound.-Layer Meteor., 69, 1-25.

Durand, P., G. Abadie, and A. Druilhet, 1995: Turbulent moisture measurements aboard instrumented aircraft with a capacitive sensor. J. Atmos. Oceanic Technol., 12, 970-978.

Durran, D. R., 1995: Do breaking mountain waves decelerate the local mean flow? J. Atmos. Sci., 52, 4010-4032.

Elkhalfi, A., and B. Carissimo, 1993: Numerical simulations of a mountain wave observed during the Pyrénées Experiment: Hydrostatic/nonhydrostatic comparison and time evolution. Contrib. Atmos. Phys., 66, 183-200.

simulations of mountain waves observed during the PYREX experiment. Mon. Wea. Rev., 123, 2149-2164.

Flamant, C., and J. Pelon, 1996: Atmospheric boundary layer structure over the Mediterranian during a Tramontane event. Quart. J. Roy. Meteor. Soc., 122, 1741-1778.

Garcia-Moya, J. A., B. Albarran, and E. Rodriguez, 1992: Experimentos numericos sobre situaciones PYREX usando diferentes versiones del LAM (INM). Encuentro Meteo 92I Congreso Iberoamericano, 5th Congreso Interamericano de Meteorologia, Salamanca, Spain, Spanish Society of Meteorology, 131-146.

Genoves, A., J. Campins, A. Jansa, P. Bessemoulin, E. Koffi, and B. Benech, 1994: Pyrenean pressure drag: Some factors and consequences after PYREX. 23d Int. Tagung fur Alpine Meteorologie, Lindau, Germany, Deutsche Wetter Dienst, 159-162.

Georgelin, M., and E. Richard, 1996: Numerical simulation of flow diversion around the Pyrenees: A Tramontana case study. Mon. Wea. Rev., 124, 687-700.

,,-- M. Petitdidier, and A. Druilhet, 1994: Impact of subgrid-scale orography parameterization on the simulation of orographic flows. Mon. Wea. Rev., 122, 1509-1522.

,$- \ldots$, and _ 1996: The impact of diurnal cycle on a low Froude number flow observed during the PYREX experiment. Mon. Wea. Rev., 124, 1119-1131.

Hedde, T., and P. Durand, 1994: Turbulence intensities and bulk coefficients in the surface layer above the sea. Bound.-Layer Meteor., 71, 415-432.

Hunt, J. C. R., and W. H. Snyder, 1980: Experiments on stably and neutrally stratified flow over a model three-dimensional hill. J. Fluid Mech., 96, 671-704.

Koffi, E. N., 1994: Caractérisation expérimentale de l'ecoulement atmosphérique autour d'un massif montagneux (expérience PYREX). Ph.D. thesis, Université Paul Sabatier, 213 pp.

Kotroni, V., and C. Mazaudier, 1993: Influence of orographic and canopy conditions on friction velocities observed during frontal events using Doppler sodar observations. J. Appl. Meteor., 32, 506-521.

Lott, F., 1995: Comparison between the orographic response of the ECMWF model and the PYREX 1990 Data. Quart. J. Roy. Meteor. Soc., 121, 1323-1348.

—_, and M. Miller, 1997: A new subgrid-scale orographic drag parameterization: Its formulation and nesting. Quart. J. Roy. Meteor. Soc., 123, 101-127.

Mason, P. J., 1988: The formation of areally-averaged roughness lengths. Quart. J. Roy. Meteor. Soc., 114, 399-420.
Masson, V., and P. Bougeault, 1996a: Nonhydrostatic simulations of real mountain flows observed during the PYREX experiment. Seventh Conf. on Mesoscale Processes, Reading, United Kingdom, Amer. Meteor. Soc., 307-309.

$\longrightarrow$, and — 1996b: Numerical simulation of a low-level wind created by complex orography: A Cierzo case study. Mon. Wea. Rev., 124, 701-715.

Mesinger, F., R. L. Wobus, and M. E. Baldwin, 1996: Parameterization of form drag in the eta model at NCEP. Preprints, 11 th Conf. on Numerical Weather Prediction, Norfolk, VA, Amer. Meteor. Soc., 324-326.

Navascués, B., 1992: Experimentos de sensibilidad de la version del analysis LAM a la resolucion 0.455 sobre una situacion PYREX. Instituto Nacional de Meteorologia Servicio de Prediccion Numerica, Nota Tecnica 22, 45 pp. [Available from INM, Apt. 285, 28071 Madrid, Spain.]

Olafsson, H., and P. Bougeault, 1997: The effect of rotation and surface friction on orographic drag. J. Atmos. Sci., 54, 193210.

Pelon, J., P. H. Flamant, and M. Meissonier, 1990: The French airborne backscatter lidar LEANDRE 1: Conception and operation. NASA Conf. Publ. 3158.

Petitdidier, M., 1996: Observations of orographic effects with a UHF ST radar during the PYREX experiment: Case study of a reversed flow associated to a lee vortex. Seventh Workshop on Technical and Scientific Aspects of MST Radars, Hilton Head Island, SC, NOAA.

- and Coauthors, 1990: The 961/45 MHz bifrequency INSU/METEO stratospheric-tropospheric radar. Meteor. Rundsch., 42, 142-151.

- E. Brunaud, O. Shojaei, C. Amory-Mazaudier, P. Bessemoulin, G. Jaubert, and J. L. Caccia, 1994: Orographic effects described by colocated sodar, UHF and VHF wind profilers during the PYREX experiment. Third Int. Symp. on Tropospheric Profiling: Needs and Technologies, Hamburg, Germany, Deutsche Meterologische Gosellschaft, University of Hamburg, 145-147.

Reisner, J. M., and P. K. Smolarkiewicz, 1994: Thermally forced low Froude number flow past three-dimensional obstacles. J. Atmos. Sci., 51, 117-133.

Salvayre, L., 1993: Etude de la POI6 de PYREX. Rapport de Stage de DEA, Université Paul Sabatier, 60 pp. [Available from CNRM, 42, avenue Gustave Coriolis, 31057 Toulouse Cedex, France.]

Satomura, T., 1996: Supplement to numerical simulation of lee wave event over the Pyrenees. J. Meteor. Soc. Japan, 74, 147-153.

events over the Pyrenees. J. Meteor. Soc. Japan, 72, 173-195.

Stein, J., 1992: Contribution à l'étude des régimes hydrostatiques d'écoulements orographiques. Ph.D. dissertation, Université Paul Sabatier, 250 pp.

von der Emde, K., and P. Bougeault, 1997, Simulation of a highly resolved flow across the Pyrénées. Meteor. Atmos. Phys., in press.

Tannhauser, D. S., and J. L. Attié, 1995: Linear analysis of the wavefield during a lee wave event of the PYREX campaign. Meteor. Z., 4, 203-208. 